\title{
Presence of anti-Leptospira spp. antibodies in captive yellow-spotted river turtles (Podocnemis unifilis) in the Eastern Amazon
}

\author{
Juliana Maria Santos Miranda ${ }^{1}$ Katarine de Souza Rocha ${ }^{2}$ D \\ Louysse Helene Monteiro ${ }^{3}$ Ianny Watuzy Monteiro Baia ${ }^{4}$ (D) \\ Thamillys Rayssa Marques Monteiro ${ }^{5}$ (D) Jacqueline da Silva Brito ${ }^{2}$ (D) \\ Ellen Yasmin Eguchi Mesquita ${ }^{6}$ Carla Cristina Guimarães de Moraes $^{7 *}(\mathbb{D}$
} 'Residência Multiprofissional em Área da Saúde, Especialidade de Medicina de Animais Selvagens, Setor Ambulatório de Animais Selvagens,
Universidade Federal da Amazônia (UFRA), Belém, PA, Brasil.
${ }^{2}$ Programa de Pós-graduação em Saúde Animal na Amazônia (PPGSAAM), Laboratório de Zoonoses e Saúde Pública, Instituto de Medicina
Veterinária, Universidade Federal do Pará (UFPA), Castanhal, PA, Brasil.
${ }^{3}$ Residência Multiprofissional em Área da Saúde, Especialidade de Clínica Médica e Cirurgia de Animais Silvestres, Instituto de Medicina
Veterinária, Universidade Federal do Pará UFPA, Castanhal, PA, Brasil.
${ }^{4}$ Médica Veterinária Autônoma, Belém, PA, Brasil.
${ }^{5}$ Residência Multiprofissional em Área da Saúde, Especialidade de Medicina Veterinária Preventiva, Instituto de Saúde e Produção Animal
(ISPA), Universidade Federal Da Amazônia (UFRA), Belém, PA, Brasil.
${ }^{6}$ Médica Veterinária do Bosque Rodrigues Alves, Universidade da Amazônia (UNAMA), Belém, PA, Brasil.
${ }^{7}$ Laboratório de Zoonoses e Saúde Pública, Instituto de Medicina Veterinária, Universidade Federal do Pará UFPA, 68746360, Castanhal, PA,
Brasil. E-mail: ccmoraes@ufpa.br. ${ }^{*}$ Corresponding author.

ABSTRACT: We describe anti-Leptospira spp. agglutinin in yellow-spotted river turtles (Podocnemis unifilis)in the Amazon region. Ninetyeight serum samples from individuals housed at the Bosque Rodrigues Alves Zoobotanical Garden of Amazonia, Belém, PA, Brazil, were subject to the microscopic agglutination test (MAT) using 19 different Leptospira spp. antigen serogroups. Thirty-four of the 98 samples (35\%) were reactive, with titers ranging from 100 to 3200, and eight 8 reactive samples $(23.5 \%)$ co-agglutinated under two or more serovars. The most common serogroup was Hebdomadis (26.9\%, 7/26), followed by Semaranga (23\%, 6/26), Shermani (19.2\%, 5/26), Djasiman (11.5\%, 3/26), and Australis (7.7\%, 2/26); Bataviae, Javanica, and Sejroewere represented by a single sample each (3.9\%). The presence of turtles reactive to anti-Leptospira spp. antibodies implies exposure to the pathogen.

Key words: Testudines, microscopic agglutination test, Hebdomadis, Amazon Region.

Presença de anticorpos anti-Leptospira spp. em tracajás (Podocnemis unifilis) na Amazônia Oriental

RESUMO: Este trabalho descreve a detecção de aglutininas anti-Leptospira spp. em tracajás (Podocnemis unifilis) na região Amazônica. Obtivemos 98 amostras de soro, as quais foram submetidas ao teste de aglutinação microscópica (MAT), utilizando 31 antígenos de diferentes sorogrupos de Leptospira spp. Das 98 amostras de soro coletadas, 35\% (34/98) reagiram apresentando titulações de 100 a 3200; 23,53\% dessas amostras (8/34) coaglutinaram na presença de dois ou mais sorovares. O sorogrupo mais comum foi Hebdomadis com 26,9\% (7/26), seguido de Semaranga com 23\% (6/26), Shermani com 19,2\% (5/26), Djasiman com 11,5\% (3/26), e Australis com 7,7\% (2/26). Bataviae, Javanica, e Sejroe foram representados com apenas uma amostra (3,9\%). A presença de tracajás reagentes a anticorpos contra Leptospira spp. implica na exposição ao patógeno.

Palavras-chave: Testudines, teste de aglutinação microscópica, Hebdomadis, Região Amazônica.

Leptospirosis, a cosmopolitan anthropozoonosis originating from Leptospira spp., exhibits pathogenic or saprophytic characters. Studies involving its epidemiological cycle in reptiles are rare in the literature (FORNAZARI, 2017). But, Leptospira spp. has been reported in multiple aquatic environments. Therefore, aquatic species with overlapping distributions may be exposed to this pathogenic agent. One candidate species for examining potential Leptospira spp. infection is the yellow-spotted river turtle (Podocnemis unifilis), known as tracajá in the Amazon region (MARVULO \& CARVALHO, 2014; EBANI, 2017). Therefore, the present study aimed to detect the occurrence of antiLeptospira spp. antibodies in P. unifilis maintained at the Bosque Rodrigues Alves Zoobotanical Garden of Amazonia, Belém, PA, Brazil. Captive specimens were selected for this analysis because wild animals 
are typically asymptomatic carriers, which may hinder infection diagnosis and treatment. Nevertheless, few serologic investigations have been performed in captivity including zoos, research centers, and breeding centers (SILVA et al., 2010; EBANI, 2017).

The studied specimens inhabited artificial lakes alongside other turtle species. These lakes communicate with tanks containing other animals such as the spectacled caiman (Caiman crocodilus). Water is only replaced when the enclosures are completely drained for cleaning, and the 98 P. unifilis examined in the present study were captured manually during these full-drain periods, with the exception of those in one tank that could not be emptied; here, a net was used instead. All P. unifilis were healthy, without clinical signs of infection.

Blood samples (1-2 mL) were collected aseptically from dorsal tail veins of physically restrained turtles using 3-mL syringes and $25 \times$ 7 needles, immediately stored in tubes without anticoagulant, and sent to the Laboratory of Zoonoses and Public Health, Institute of Veterinary Medicine, Federal University of Pará (IMV/UFPA), Brazil. Samples were centrifuged to extract the serum, and serum samples were transferred to Eppendorf micro tubes and stored at $-20{ }^{\circ} \mathrm{C}$ for serological tests.

The presence of anti-Leptospira spp. antibodies was assessed using the microscopic agglutination test (MAT) (FAINE, 1999), and been used 31 standard strains. The seeds derived from these strains used in the present research were four months old and grown in culture medium at our laboratory, allowing retrieving 19 serogroups:
Australis, Autumnalis, Ballum, Bataviae, Canicola, Celedoni, Cynopteri, Djasiman, Grippotyphosa, Hebdomadis, Icterohaemorrhagiae, Javanica, Pamana, Pomona, Pyrogenes, Sejroe, Shermani, Andamana, and Seramanga. Samples with $\geq 50 \%$ agglutination compared to the control sample were considered reactive and were sent for titration with the cutoff point set at 100 , considering this value as the dilution.

Thirty-four of the 98 samples $(35 \%)$ were reactive, eight of which (23.5\%) co-agglutinated under two or more serovars under the same titration. As this result precluded the determination of a predominant serovar and frequency was not calculated for these samples. Among the remaining 26 for which frequency could be calculated, the most common serogroup was Hebdomadis $(26.9 \%, 7 / 26)$, followed by Semaranga (23\%, 6/26), Shermani (19.2\%, 5/26), Djasiman (11.5\%, $3 / 26)$, and Australis(7.7\%, 2/26). Bataviae, Javanica, and Sejroe were each represented by a single sample (3.9\%).Titers ranged from 100 to 3200 (Table 1).

Agglutinins were detected for eight serogroups, with Hebdomadis being the most frequent. This serogroup was not identified for $P$. unifilis in the Amazon, as this species is typically reported in the northern Amazon region. However, a frequent Hebdomadis serogroup has been described for other wild animal species and cattle (MINEIRO et al., 2007; LENHARO et al., 2012;RODRIGUES et al., 2012). Due to the lack of serologic studies in P. unifilis, we compared our findings with that obtained for other turtle species, including Geochelones spp., red-eared tortoise, Amazonian tortoise, and water tiger.

Table 1 - Serogroups and titers most frequently detected by the microscopic agglutination test for anti-Leptospira spp. antibodies in 26 reactive serum samples of yellow-spotted river turtle specimens collected at the Bosque Rodrigues Alves Zoobotanical Garden in Belém, PA, Brazil.

\begin{tabular}{|c|c|c|c|c|c|c|c|c|}
\hline \multirow[t]{2}{*}{ Serogroups } & $-\cdots$ & --- & ----- & ----- & ----- & ------- & \multirow[t]{2}{*}{ Total } & \multirow[t]{2}{*}{$(\%)$} \\
\hline & 100 & 200 & 400 & 800 & 1600 & 3200 & & \\
\hline Australis & - & 1 & 1 & - & - & - & 2 & 7.7 \\
\hline Bataviae & - & - & - & - & - & 1 & 1 & 3.9 \\
\hline Djasiman & 1 & 1 & 1 & - & - & - & 3 & 11.5 \\
\hline Hebdomadis & 2 & 3 & 2 & 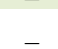 & - & - & 7 & 26.9 \\
\hline Javanica & - & - & - & 1 & - & - & 1 & 3.9 \\
\hline Shermani & 1 & 1 & 3 & - & - & - & 5 & 19.2 \\
\hline Semaranga & 3 & 1 & 1 & - & - & 1 & 6 & 23 \\
\hline Sejroe & 1 & - & _- & - & - & - & 1 & 3.9 \\
\hline Total & 8 & 7 & 8 & 1 & 0 & 2 & 26 & 100 \\
\hline
\end{tabular}


Reactivity to Semaranga (serovar Patoc), the second most common serogroup in our study, has been reported incaptive Geochelones spp. And Trachemys scripta (pond slider) (ESTEVES et al., 2005; SILVA et al., 2010). Despite originatingfrom the non-pathogenic and saprophytic Leptospira biflexa, detecting Semaranga has important implications for anthropozoonosis because its presence may stimulate an immune response and trigger crossreactions with other pathogenic serovars (MYERS, 1976; PAZ et al., 2015). This might be the reason why Semaranga and Bataviae serogroups had the highest titers (3200). Bataviae has also been detected in Trachemys dorbigni (D'Orbigny's slider) (SILVA et al., 2009).

Because the water at the enclosures where $P$. unifilis live are freely accessible to other species, it may become a reservoirof Leptospira spp. Mammals, in particular, might be sources of infection for P. unifilis. Thus, serological tests for the diagnosis of serovars belonging to the serogroups identified in the present study have been conducted in rodents; PAIXÃO et al. (2014) detected samples of rats captured in a wild animal preservation reactive to the serogroups identified for $P$. unifilis, while MESQUITA et al. (2018) detected samples of Didelphis marsupialis (common opossum), a common mammal in the region, reactive to the icterohaemorragiae and Nupezo serogroups, which are different from the ones detected in this study.

The scarcity of published serogroup research on wild animals inhabiting the study region does not convey an appropriate context for discussing the diversity of serogroups identified in the present study. A better understanding of the serovars present in the study region may allow us to consolidate the serogroups reported here. Data on P. unifilis origin and associations with other species prior to arrival at our study site would also greatly benefit future serogroup analyses.

In addition to regular serologic tests on animals to better understand the infection risk, hygienic and sanitary measures are necessary in captive environments. These include regular sanitization of enclosures, removal of synanthropic animals, analysis of water quality, and implementation of a quarantine period before the introduction of a new specimen (PÉREZ-FLORES et al., 2016; ESTEVES-MACHADO et al., 2010; RATAJ et al., 2011; RODRIGUES et al., 2016; DETTUZZO, et al., 2017; EBANI, 2017). Such measures can minimize pathogen incidence in zoos and other facilities were animals are held captive.
In conclusion, this study successfully detected anti-Leptospira $\mathrm{spp}$. antibodies in P. unifilis, an Amazonian turtle species held in captivity, providing direct evidence that this population has been exposed to the pathogen.

\section{ACKNOWLEDGEMENTS}

We would like to thank Coordenação de Aperfeiçoamento de Pessoal de Nível Superior (CAPES) for granting the scholarship and Amazon Zoobotanical Park for their assistance in capturing the animals examined in this study and collecting biological samples for this work.

\section{ETHICS AND BIOSAFETY COMMITTEE}

This study was approved by the Brazilian Biodiversity Authorization and Information System - SISBIO (permit no. 59785-1)

\section{DECLARATION OF CONFLICT OF INTERESTS}

The authors declare no conflict of interest. The founding sponsors had no role in the design of the study; in the collection, analyses, or interpretation of data; in the writing of the manuscript, and in the decision to publish the results.

\section{AUTHORS' CONTRIBUTIONS}

The authors contributed equally to the manuscript.

\section{REFERENCES}

DETTUZZO, D; et al. Detection of Leptospira spp. in Water Turtle (Trachemys scripta) Living in Ponds of Urban Parks. Vet. Sci. 2017, 4, 51. Available from: <https://www.ncbi.nlm.nih.gov/pmc/ articles/PMC5753631/pdf/vetsci-04-00051.pdf $>$. Accessed: Jan. 05, 2018. doi:10.3390/vetsci4040051.

EBANI, V.V. Domestic reptiles as source of zoonotic bacteria: A mini review. Asian Pacific Journal of Tropical Medicine, 2017; 10(8): p. 723-728. Available from: <https://doi.org/10.1016/j. apjtm.2017.07.020>. Accessed: Dec. 20, 2017.

ESTEVES, F. M.; et al. Detecção de anticorpos para Leptospira spp. em animais e funcionários do zoológico municipal de Uberaba, MG. Arq. Inst. Biol., São Paulo, v.72, n.3, p.283-288, jul/set.,2005.Available from: <http://www.biologico.sp.gov.br/ uploads/docs/arq/V72_3/esteves.PDF>. Accessed: Dec. 20, 2017.

ESTEVES-MACHADO, F.M; et al. plano de ação para o controle da leptospirose no Zoológico Municipal de Uberaba-MG.Biosci. J.,Uberlândia, v.26, n.6, p.981-989, Nov./Dec. 2010. Available from: <http://www.seer.ufu.br/index.php/biosciencejournal/article/ view/7242> . Accessed: Dec. 20, 2017.

FAINE, S. et al. Leptospira and Leptospirosis. Melbourne: Medisci, Australia, 1999. 272p.

FORNAZARI, F. Are Reptiles Reservoirs of Leptospirosis? A Brief Discussion Based on Seriological Studies. Eco Health 14,p.203-204, 2017. 
Available from: <https://www.ncbi.nlm.nih.gov/pubmed/28500422>. Accessed: Jul. 05, 2019.doi: 10.1007/s10393-017-1243-Z

LENHARO, D.K. et al. Avaliação sorológica para leptospirose em mamíferos silvestres procedentes do parque zoológico municipal de Bauru, SP. Arq. Inst. Biol., São Paulo, v.79, n.3, p.333-341, julset., 2012. Available from: <http://www.scielo.br/pdf/aib/v79n3/ a03v79n3.pdf>. Accessed: Dec. 20, 2017.

MARVULO, M. F. V \& CARVALHO, V. M in: CUBAS, Z. S Tratado de animais selvagens: medicina veterinária/ Zalmir Silvino Cubas, Jean Carlos Ramos Silva, José Luiz Catão-Dias- $2^{\circ}$ ed. São Paulo: Roca, 2014. p. 2200.

MESQUITA, G. S. S; et al. Detection of antibodies against Leptospira spp in free-living marsupialis caught in the Eastern Amazon. Rev. Soc. Bras. Med Trop 51 (3): 368-371, MayJun, 2018. Available from: <http://www.scielo.br/pdf/rsbmt/ v51n3/1678-9849-rsbmt-51-03-368.pdf>. Accessed: Jul. 05, 2019. doi: 10.1590/0037-8682-0236-2017.

MINEIRO, A.L.B.B. et al. Leptospiral infection in bovine and its association with reproductive failure and climatic conditions. Arq. Bras. Med. Vet. Zootec., v.59, n.5, p.1103-1109, 2007. Available from: <http://www.scielo.br/pdf/abmvz/v59n5/a03v59n5.pdf $>$. Accessed: Nov. 15, 2017

MYERS, D. M. Serological studies and isolations of serotype hardjo and Leptospira biflexa Strains from Horses of Argentina. Journal of clinical microbiology, June 1976, vol.3. n.6, p.548555 Copyright ${ }^{\circ} \mathrm{D} 1976$ American Society for Microbiology. Available from: <https://jcm.asm.org/content/jcm/3/6/548.full. pdf $>$. Accessed: Jan. 20, 2018.

PAIXÃO, M.S. et al. Serology, isolation, and molecular detection of Leptospira spp. from the tissues and blood of rats captured in a wild animal preservation centre in Brazil. Prev. Vet. Med., v.115, n.1-2, p.69-73, 2014.Available from: <https://doi.org/10.1016/j. prevetmed.2014.03.016>. Accessed: Nov. 16, 2019.

PAZ, G. S.et al. Seroprevalence for brucellosis and leptospirosis in dogs from Belém and Castanhal, State of Pará, Brazil. Acta
Amazonica VOL. 45(3) 2015: 265 - 270. Available from: <http:// dx.doi.org/10.1590/1809-4392201403486>. Accessed: Jan. 20, 2018. Doi: 10.1590/1809-4392201403486.

PÉREZ-FLORES, J.et al. Evidence for Wild Crocodiles as a Risk for Human Leptospirosis, Mexico. International Association for Ecology and Health, vol.14 (2016). p.58-68. Available from: $<$ https://www.ncbi.nlm.nih.gov/pubmed/27807634>. Accessed: Jan. 20, 2018. doi: 10.1007/s10393-016-1196-7.

RATAJ, A.V.et al. Parasites in pet reptiles. Acta VeterinariaScandinavica, 2011, 53:33.Available from: $<$ https:// actavetscand.biomedcentral.com/track/pdf/10.1186/1751-014753-33>. Accessed: Jan. 20, 2018.

RODRIGUES, T.C.S. et al. Ocorrência de anticorpos contra Leptospira spp. em canídeos selvagens de vida livre do cerrado brasileiro. Vet. Not., Uberlândia, v.18. n.2 (supl), p.51-56, jul-dez. 2012.Available from: <https://www.academia.edu/26596643/ OCORR\%C3\%8ANCIA DE ANTICORPOS CONTRA Leptospira_spp._EM_CAN $\% \bar{C} 3 \% 8 D D E O S \_S E L V A G E N S$ DE VIDA LIVRE DO CERRADO BRASILEIRO>. Accessed: Jan. 20, 2018.

RODRIGUES, T.C.S.et al.Anti-Leptospira spp. antibodies in Crotalus durissus collilineatus kept in captivity and its zoonotic relevance. Acta Tropica 158 (2016) 39-42.Available from: $<$ http://europepmc.org/abstract/med/26875762>. Accessed: Jan. 10, 2018. doi: 10.1016/j.actatropica.2016.02.006.

SILVA, E.F.et al. Serum antileptospiral agglutinins in freshwater turtles from Southern Brazil. Brazilian Journal of Microbiology (2009) 40:227-230. Available from: <http://dx.doi.org/10.1590/ S1517-83822009000200003>. Accessed: Jan. 10, 2018. doi: 10.1590/S1517-83822009000200003.

SILVA, C.S. et al. Anti- Leptospira spp. Antibodies in wild animals from RibeirãoPretocity zoo in São Paulo State, Brazil. Braz. J. Vet. Res. Anim. Sci., São Paulo, v.47, n3, p.237-242, 2010. Available from: <http://www.revistas.usp.br/bjvras/article/ view/26862/28645>. Accessed: Jan. 10, 2018. 